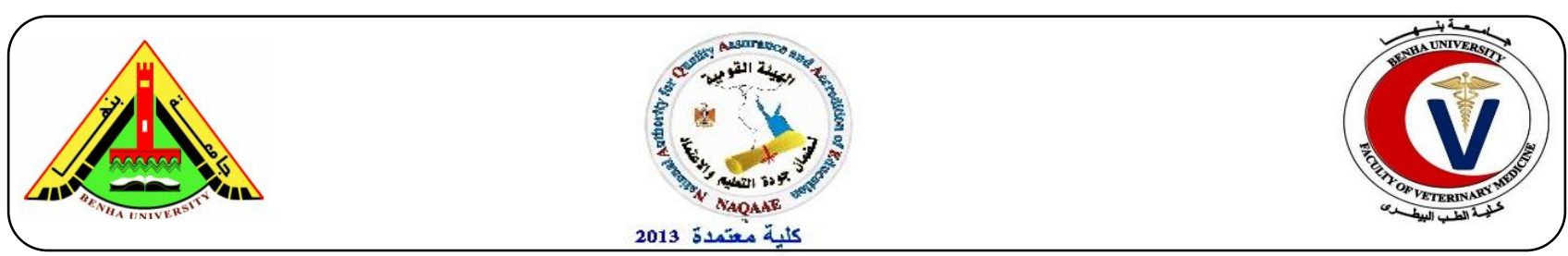

\title{
Biochemical Study of Anti-Inflammatory Effect of Osteoblastic Activator in Experimental Pancreatic Degeneration in Rat
}

\author{
Abdel maksoud H.A.; Omnia M. A. and El-Bialy M. \\ Department of Meat Biochemistry, Faculty of Veterinary Medicine, Benha University
}

\begin{abstract}
A B S T R A C T
A total number of 160 Wister female rats, 12 -wk. old were, weighed and divided into five experimental groups to investigate the effect of streptozotocin (STZ) injection (30 and $60 \mathrm{mg} / \mathrm{kg}$ B.W) with and without zoledronic acid $(0.15 \mathrm{mg} / \mathrm{kg} \mathrm{B.W})$ on some blood serum constituents such as interleukins (IL-2, IL-6), immunoglobulin E (IgE) and cortisol. The results indicated that it's paralleled to the published data on the hyperglycemia and inflammatory condition in experimentally pancreatic degeneration. The current results showed that, injection with STZ was associated with a statistically significant elevation in serum IL-2, IL-6, IgE and cortisol but zoledronic treatment with STZ resulted in a decrease in serum IL-2, IL-6, IgE and cortisol. These results indicated that ZOL acid has beneficial effect to slow pancreatic carcinoma induction when treated with STZ at once in experimental animals.
\end{abstract}

Keywords: STZ, Zoledronic acid, pancreas.

(http://www.bvmj.bu.edu.eg) (BVMJ-35(1): 164-170, 2018)

\section{INTRODUCTION}

Pancreatic degeneration creates a highly immunosuppressive tumor microenvironment though the production of inhibitory cytokines and the recruitment of immunosuppressive cells (Lechner et al., 2010), including $\mathrm{T}$ regulatory cells.

Bisphosphonates (BP) are currently the most important class of inhibitors of osteoclastmediated bone resorption and are used extensively for the treatment of skeletal diseases, such as Paget's disease, (Silverman, 2008) postmenopausal osteoporosis (Black et al., 2007) and tumor induced osteolysis. (Coleman, 2004). Some studies showed that zoledronic acid (ZOL) demonstrates antitumor activity in several human neoplasms such as myeloma, colon (Sewing et al., 2008) and pancreatic cancers (Tassone et al., 2003). Furthermore, ZOL has been reported to inhibit proliferation and induce apoptosis of tumor cells through the mevalonate pathway (Benford et al., 1999) by preventing the translocation of small GTPase Ras to the plasma membrane. Recently, Li et al. (2011) published a report showing the ability of ZOL to inhibit invasion and migration through down regulation of vascular endothelial growth factor (VEGF) and matrix metalloproteinase (MMP) in human nasopharyngeal carcinoma cells in vitro. Therefore, the objective of this study aimed to investigate the potential effect of 
zoledronic acid on some inflammatory parameters of degenerated pancreas by using STZ.

\section{Materials and methods}

This study was carried out at biochemistry Dept., faculty of veterinary medicine, Benha University. One hundred and Sixty Wister female rats, 12 -wks-old were divided into five experimental groups. Rats were housed in separate metal cages, then the five experimental groups were arranged as, the first as a control group (un-treated), the second group injected with $30 \mathrm{mg}$ STZ/ kg $\mathrm{BW}$, the third group injected with $60 \mathrm{mg}$ STZ $/ \mathrm{kg}$, the fourth group injected with $30 \mathrm{mg}$ STZ plus $0.15 \mathrm{mg} Z \mathrm{ZOL} / \mathrm{kg}$ and the fifth group injected with $60 \mathrm{mg}$ STZ plus $0.15 \mathrm{mg} \mathrm{ZOL/}$ $\mathrm{kg} \mathrm{BW}$ to studying their effects on some sera contents such as interleukins (IL2\&IL6), immunoglobulin $\mathrm{E}(\mathrm{IgE})$ and cortisol at 14 and 28 day after treatment.

Experimental partial degenerated pancreas was induced by a single intraperitoneal injection of streptozotocin with $30 \mathrm{mg} / \mathrm{kg}$ and completely degenerated pancreas was induced by a single intraperitoneal injection of streptozotocin by $60 \mathrm{mg} / \mathrm{kg}$. Streptozotocin (Sigma Chemicals Co, St. Louis, MO, USA). It was dissolved in cold $0.01 \mathrm{M}$ citrate buffer, $\mathrm{pH} 4.5$ and always freshly prepared for immediate use within 5 min. STZ injections were given intraperitoneally and the doses were determined according to the body weight of animals (Hamilton et al., 1998). Zoledronic acid was purchased it from Global Napi pharmaceuticals Co. (Metadronic vial) and injected by $0.15 \mathrm{mg} / \mathrm{kg} \mathrm{BW}$ through the tail vein.

\section{Data collection and estimated parameters:}

At 14 and 28 day after treatment start, blood samples were collected in centrifuge tubes from four rats per each treatment without anticoagulant and kept at room temperature for one hour to clot. The samples were centrifuged at $3500 \mathrm{rpm}$ for 15 minutes to separate clear serum. After that, serum IL-2 and IL-6 (Robb , 1984), IgE (Bergstrand and Scand , 1956) and serum cortisol were determined using available commercial Kits.

\section{Statistical analysis:}

Data obtained were statistically analyzed using the general linear model of SAS (2004), as follows: $\mathrm{Yik}=\mu+\mathrm{Ti}++$ eik where : Yik $=$ an observation; $\mu=$ Overall mean; $\mathrm{T}=$ Effect of treatment; $\mathrm{i}=(1,2, \ldots$ and 5$)$; and eik $=$ Random error. Significant differences among treatments means were tested by Duncan's multiple range test (Duncan, 1955).

\section{RESULTS}

A significant differences $(\mathrm{P} \leq 0.01)$ were observed in serum interleukin 2 (IL-2) content among experimental groups at 14 and 28 day after treatment (Table 1). Serum IL-2 was significantly $(\mathrm{P} \leq 0.01)$ elevated for rats injected by STZ with or without ZOL than the control. However, ZOL injection plus STZ at the same time resulted in a significant decrease in serum IL-2 content than those injected with STZ only at 14 or 28 day after treatment. The group treated with $30 \mathrm{mg} \mathrm{STZ}$ with or without ZOL recorded the lower value of IL-2 than those treated with $60 \mathrm{mg} \mathrm{STZ}$ at 14 or 28 day after treatment.

Results of Table 2 shows a significant differences $(\mathrm{P} \leq 0.01)$ in serum interleukin 6 (IL-6) content among experimental groups at 14 and 28 day after treatment. Serum IL-6 was significantly $(\mathrm{P} \leq 0.01)$ elevated for rats injected by STZ than the control. However, ZOL injection plus STZ at the same time resulted in a significant decrease in serum IL6 content than those injected with STZ only at 14 or 28 day after treatment. The group treated with $30 \mathrm{mg} \mathrm{STZ}$ with or without ZOL recorded the lower value of IL- 6 than those 
treated with $60 \mathrm{mg} \mathrm{STZ}$ at 14 or 28 day after treatment. Generally, serum IL-6 content was elevated for all treated groups at 28 day after treatment as compared with their levels at 14 day for the same treated groups especially the group treated with both STZ dosses. The injection with Zol plus STZ resulted in more decrease in IL-6 at 28 day than 14 day after treatment.

Serum $\operatorname{IgE}$ and was significantly $(\mathrm{P} \leq 0.01)$ elevated for all treated groups by STZ with or without ZOL than the control group (untreated) at 14 and 28 day after treatment (Table 3). Serum IgE was significantly higher of rats injected by $60 \mathrm{mg}$ STZ/ $\mathrm{kg}$ as compared with those treated with $30 \mathrm{mg} \mathrm{STZ}$, while it was significantly $(\mathrm{P} \leq 0.01)$ lowered for treated groups with ZOL plus STZ than those treated with STZ only. Rats treated with
ZOL plus $30 \mathrm{mg} \mathrm{STZ} \mathrm{had} \mathrm{significantly} \mathrm{lower}$ value of serum $\operatorname{IgE}$ as compared to other treated groups.

Serum cortisol was significantly $(\mathrm{P} \leq 0.01)$ elevated for all treated groups by STZ with or without ZOL than the control group (untreated) at 14 and 28 day after treatment (Table 4). Serum cortisol content was higher for rats injected with $60 \mathrm{mg}$ STZ/ $\mathrm{kg}$ than those treated with $30 \mathrm{mg} \mathrm{STZ}$. Injection with ZOL plus STZ resulted in a decrease in serum cortisol than those treated with the same STZ dose only at 14 or 28 day after treatment. Generally, serum cortisol was elevated for all treated groups at 28 day than 14 day after treatment.

Table 1: Effect of streptozotocin (STZ) injection with or without zoledronic (ZOL) on serum interleukin 2 (IL-2) content at 14 and 28 day after treatment.

\begin{tabular}{lcc}
\hline \multirow{2}{*}{ Experimental groups } & \multicolumn{2}{c}{ Period after treatment, day } \\
\cline { 2 - 3 } & $\overline{\mathrm{X}} \pm \mathrm{SE}$ & 28 \\
\hline T1 (Control, -ve) & $0.65 \pm 0.10^{\mathbf{d}}$ & $\overline{\mathrm{X}} \pm \mathrm{SE}$ \\
T2 ( 30 mg STZ) & $3.16 \pm 0.15^{\mathbf{b}}$ & $0.65 \pm 0.10^{\mathbf{c}}$ \\
T3 (60 mg STZ ) & $4.14 \pm 0.10^{\mathbf{a}}$ & $4.42 \pm 0.13^{\mathbf{a}}$ \\
T4 (30 mg STZ + ZOL) & $1.37 \pm 0.26^{\mathbf{c}}$ & $5.1 \pm 0.32^{\mathbf{a}}$ \\
T 5 (60 mg STZ + ZOL) & $1.68 \pm 0.20^{\mathbf{c}}$ & $2.35 \pm 0.23^{\mathbf{b}}$ \\
Significant & $*_{*}$ & $2.87 \pm 0.30^{\mathbf{b}}$ \\
\hline
\end{tabular}

a,b,c... $\mathrm{d}$ :means in the same column within each item bearing different superscripts are significantly different $(\mathrm{P} \leq 0.05), \mathrm{SE}=$ stander error; $* *=$ significant at $\mathrm{P} \leq 0.01$

Table 2: Effect of streptozotocin (STZ) injection with or without zoledronic (ZOL) on serum interleukin 6 (IL-6) content at 14 and 28 day after treatment.

\begin{tabular}{ccc}
\hline & \multicolumn{2}{c}{ After the beginning of treatment, day } \\
\cline { 2 - 3 } Experimental groups & 14 & 28 \\
\cline { 2 - 3 } & $\overline{\mathrm{X}} \pm \mathrm{SE}$ & $\overline{\mathrm{X}} \pm \mathrm{SE}$ \\
\hline T1 (Control, $\left.{ }^{-}\right)$ & $6.86 \pm 0.19^{\mathrm{c}}$ & $6.86 \pm 0.19^{\mathrm{c}}$ \\
T4 (30 mg STZ) & $9.30 \pm 0.30^{\mathrm{b}}$ & $22.20 \pm 1.75^{\mathrm{a}}$ \\
T 5 (60 mg STZ) & $12.45 \pm 0.50^{\mathrm{a}}$ & $25.26 \pm 1.80^{\mathrm{a}}$ \\
T4 (30 mg STZ + ZOL) & $7.01 \pm 0.20^{\mathrm{c}}$ & $10.92 \pm 0.70^{\mathrm{bc}}$ \\
T 5 (60 mg STZ + ZOL) & $8.71 \pm 0.27^{\mathrm{b}}$ & $15.63 \pm 2.49^{\mathrm{b}}$ \\
\hline
\end{tabular}


a,b,c... d :means in the same column within each item bearing different superscripts are significantly different $(\mathrm{P} \leq 0.05), \mathrm{SE}=$ stander error

Table 3: Effect of streptozotocin (STZ) injection with or without zoledronic (ZOL) on serum $\operatorname{IgE}$ content at 14 and 28 day after treatment.

\begin{tabular}{lcc}
\hline \multirow{2}{*}{ Experimental groups } & \multicolumn{2}{c}{ After the beginning of treatment, day } \\
\cline { 2 - 3 } & \multicolumn{1}{c}{14} & 28 \\
\cline { 2 - 3 } & $\overline{\mathrm{X}} \pm \mathrm{SE}$ & $\overline{\mathrm{X}} \pm \mathrm{SE}$ \\
\hline T1 $\left(\right.$ Control, V $\left.{ }^{-}\right)$ & $23.71 \pm 2.32^{\mathrm{d}}$ & $23.71 \pm 2.32^{\mathrm{d}}$ \\
T2 $(30 \mathrm{mg} \mathrm{STZ})$ & $92.30 \pm 7.06^{\mathrm{b}}$ & $108.35 \pm 9.07^{\mathrm{b}}$ \\
T3 $(60 \mathrm{mg} \mathrm{STZ})$ & $139.75 \pm 5.62^{\mathrm{a}}$ & $167.85 \pm 8.88^{\mathrm{a}}$ \\
T4 $(30 \mathrm{mg} \mathrm{STZ}+$ ZOL $)$ & $56.63 \pm 3.38^{\mathrm{c}}$ & $71.36 \pm 5.11^{\mathrm{c}}$ \\
T 5 $(60 \mathrm{mg} \mathrm{STZ}+$ ZOL $)$ & $87.89 \pm 6.26^{\mathrm{b}}$ & $95.56 \pm 7.39^{\mathrm{b}}$ \\
\hline
\end{tabular}

a,b,c... d :means in the same column within each item bearing different superscripts are significantly different $(\mathrm{P} \leq 0.05), \mathrm{SE}=$ stander error

Table 4: Effect of streptozotocin (STZ) injection with or without zoledronic (ZOL) on serum cortisol content at 14 and 28 day after treatment.

\begin{tabular}{|c|c|c|}
\hline \multirow{3}{*}{ Experimental groups } & \multicolumn{2}{|c|}{ After the beginning of treatment, day } \\
\hline & 14 & 28 \\
\hline & $\overline{\mathrm{X}} \pm \mathrm{SE}$ & $\overline{\mathrm{X}} \pm \mathrm{SE}$ \\
\hline T1 (Control, V) & $6.98 \pm 0.94^{c}$ & $6.98 \pm 0.94^{c}$ \\
\hline T2 ( 30 mg STZ) & $17.86 \pm 1.22^{\mathrm{ab}}$ & $34.75 \pm 5.93^{b}$ \\
\hline T3 (60 mg STZ ) & $23.03 \pm 1.92^{\mathrm{a}}$ & $51.03 \pm 3.36^{\mathrm{a}}$ \\
\hline T4 (30 mg STZ + ZOL) & $14.22 \pm 2.30^{b}$ & $30.62 \pm 3.29^{b}$ \\
\hline $\mathrm{T} 5(60 \mathrm{mg} \mathrm{STZ}+\mathrm{ZOL})$ & $22.67 \pm 2.77^{\mathrm{a}}$ & $39.50 \pm 7.14^{\mathrm{ab}}$ \\
\hline
\end{tabular}

a,b,c... d :means in the same column within each item bearing different superscripts are significantly different $(\mathrm{P} \leq 0.05), \quad \mathrm{SE}=$ stander error

\section{DISCUSSION}

During the first two or four weeks after STZ injection, glycemia rose in all treated rat groups with 30 or $60 \mathrm{mg} \mathrm{STZ} / \mathrm{kg} \mathrm{BW}$, suggesting similar acute STZ toxic effects on the endocrine pancreas. These results may be due to pancreatic $\beta$-cells were degenerated or necrosis by STZ treatment, leading a decrease in insulin secretion and an increase in blood glucose concentration. Generally, the hyperglycemia of rats which induced by treatment with 30 or $60 \mathrm{mg} \mathrm{STZ/kg} \mathrm{resulted}$ in a significant increase in some serum interleukins (IL-2 \& IL-6) at 14 and 28 days after treatment than un-treated group. These results are in agreement with those obtained by Tang et al. (2011) who found that plasma levels of IL-6 increased in rats with STZinduced diabetes. Monocyte interleukin (IL6) levels are significantly elevated in type 1 diabetic subjects (Devaraj et al., 2006). Zolderonic treatment plus STZ at once caused a significant decrease in serum interleukins (IL-2\& IL-6) than un-treated group at 14 and 28 day after treatment may be due to zoledronic acid has a direct effect on the primary tumor and plays a major role as antitumor activity (Tassone et al., 2003 ; Marten et al., 2007). Also, ZOL injection at the initial treatment of pancreatic degeneration by STZ may resulted in a delay of induce pancreatic carcinoma. Also, ZOL injection may resulted 
in a decrease of STZ capacity to induce pancreatic tumor for $\beta$-cells because ZOL by inhibit a key enzyme, farnesyl diphosphonate (FPP) synthase, in the biosynthetic mevalonate pathway (Zekri et al., 2014). These data suggest that zoledronic acid inhibits the expression and secretion of IL-6 normally produced in high levels in PC-3 cell lines. Also, zoledronic acid play anti-tumor agent which could be effected on IL-6 signaling pathways in pancreatic cells. In the literature the first data on cytotoxic effect of zoledronic acid was produced by Aparicio et al. (1998) in myeloma cell lines. Then several studies (Tassone et al., 2000; Mundy et al, 2001; Lee et al, 2002) have suggested direct anti-proliferative and pro-apoptotic effects of the bisphosphonates on myeloma cancer cells.

The hyperglycemia of rats which induced by injection STZ with 30 or $60 \mathrm{mg} \mathrm{STZ/kg} \mathrm{BW}$ resulted in a significant increase in serum $\operatorname{IgE}$ at 14 day after treatment than un-treated group. This means that, serum IgE was positively associated with higher glucose and lower insulin in experimental diabetic rats. Our findings in line with previous studies, a nested case-control design and logistic regression analysis of 135 patients with $\mathrm{CHD}$ and 135 control subjects, serum IgE levels were higher in CHD patients than in control subjects (Erdogan et al., 2003). Also, Wang et al (2011) provided the first evidence that increased plasma levels of mast cell proteases and IgE may serve as important risk factors for type 2 diabetic patients, particularly when hs-CRP or other common diabetes mellitus risk factors are considered.

A significant increase in serum cortisol of rats which injected with 30 or $60 \mathrm{mg} \mathrm{STZ/kg} \mathrm{BW}$ at 14 days after treatment than un-treated group. Generally, the interaction between several genetic and environmental factors results in a heterogeneous and progressive disorder with variable degrees of insulin resistance and pancreatic $\beta$-cell dysfunction (Stumvoll et al., 2005). Our results show that within the range of physiological normal, increasing cortisol is strongly associated with increasing diabetic pathophysiology, particularly in the variables that depend on hyperglycemia. It seems probable that the stimulatory effect of cortisol on these variables is a consequence of the direct action of cortisol on hepatic gluconeogenesis (Khani and Tayek, 2001). While, ZOL injection plus STZ at once had beneficial effects on serum cortisol, which resulted in a decrease of serum cortisol as compared with those treated with STZ only. These data suggest that zoledronic acid inhibit the expression and secretion of corticoids hormones, or ZOL may be appear to improve pancreatic $\beta$-cell function directly, that it decrease the risk of impaired glucose metabolism. So that, ZOL injection improve insulin production in pancreatic $\beta$-cell, which decrease serum glucose, then low serum cortisol levels which are a mixture of direct and indirect effects of ZOL plus STZ.

\section{Conclusion}

Based on the present data, treatment by zoledronic acid $(0.15 \mathrm{mg} / \mathrm{kg})$ combined with STZ (30 or $60 \mathrm{mg} / \mathrm{kg}$ ) might be attributed to an inhibition of invasion and proliferation of cancer cells of pancrease. So, the therapy with zoledronic may show a great promise for the treatment of pancreatic cancer at the further.

\section{REFERENCES}

Aparicio, A.; Gardner A.; Tu Y.; Savage A.; Berenson J. and Lichtenstein A., 1998. "In vitro cytoreductive effects on multiple myeloma cells induced by bisphosphonates." Leukemia. 12(2): 220-229.

Benford, H.L.; Frith J.C.; Auriola S.; Monkkonen J, and Rogers M.J., 1999. Farnesol and geranylgeraniol prevent 
activation of caspases by aminobisphosphonates: biochemical evidence for two distinct pharmacological classes of bisphosphonate drugs. Mol Pharmacol, 56: $131-40$.

Bergstrand, G.C. and Scand J., 1956. Clin Invest, 8: 174.

Black, D.M.; Delmas P.D. and Eastell R., 2007. Once-yearly zoledronic acid for treatment of postmenopausal osteoporosis. N Engl J Med, 356: 1809-1822.

Coleman, R.E., 2004. Bisphosphonates: clinical experience. Oncologist, 9(Suppl. 4): 14-27.

Devaraj, S.; Glaser N.; Griffen S.; WangPolagruto J.; Miguelino E. and Jialal I., 2006. Increased monocytic activity and biomarkers of inflammation in patients with type 1 diabetes. Diabetes, 55: 774-779.

Drake, M.T.; Clarke B.L. and Khosla S., 2008. Bisphosphonates: mechanism of action and role in clinical practice. Mmechanism of action and role in clinical practice. Mayo Clinic Proc., 83:1032-1045

Erdogan, O.; Altun A.; Gul C. and Ozbay G., 2003. Creactive protein and immunoglobulin-E response to coronary artery stenting in patients with stable angina. Japan Heart J., 44: 593-600 .

Hamilton, K.; Eaton E.J.; Garland H.O. and Old S., 1998. Effects of experimental diabetes mellitus on Gentamicininduced acute renal functional changes in the anesthetized rats.Clinical experimental Pharmacology and Physiology, 25: 231-235.
Herman, W.H.; Aubert R.E.; Ali M.A.; Sous E.S. and Badran A., 1997. Diabetes mellitus in Egypt: resk factors, prevalence and future burden. East Meditter Health J.; 3 (1): 144-148.

Khani, S. and Tayek J.A., 2001. Cortisol increases gluconeogenesis in humans: its role in the metabolic syndrome. Clinical Sci., (London) 101: 739-747.

Lechner, M.G.; Liebertz D.J. and Epstein A.L., 2010. Characterization of cytokine-induced myeloid-derived suppressor cells from normal human peripheral blood mononuclear cells. J. Immunol., 185(4):2273-2284.

Lee, Y. P.; Schwarz E. M.; Davies M.; Jo M.; Gates J.; Zhang X.; Wu J., and Lieberman J. R., 2002. "Use of zoledronate to treat osteoblastic versus osteolytic lesions in a severecombined-immunodeficient mouse model," Cancer Res., Vol. 62, No. 19, pp. 5564-5570 .

Lenzen, S., 2008. The mechanisms of alloxan- and streptozotocininduced diabetes. Diabetologia 51:216-226

Li, X.Y.; Lin Y.C. and Huang W.L., 2011. Zoledronic acid inhibits proliferation and impairs migration and invasion through downregulating VEGF and MMPs expression in human nasopharyngeal carcinoma cells. Med Oncol, doi: 10.1007/s12032-011-99041 [Epub ahead of print].

Low, S.K.; Kuchiba A. and Zembutsu H., 2010. Genome-wide association study of pancreatic cancer in Japanese population. PLoS ONE, 5: e11824.

Marten, A.; Lilienfeld-Toal M.; Buchler M.W. and Schmidt J., 2007. Zoledronic acid has direct antiproliferative and 
antimetastatic effect on pancreatic carcinoma cells and acts as an antigen for delta2 gamma/delta $\mathrm{T}$ cells. J Immunother. 30(4):370-377

Mundy, G., 2001. "Preclinical models of bone metastases, Semin.Oncol., Vol. 28, No. 4 Suppl 11, pp. 2-8 .

Németh, B.C.; Várkonyi T.; Somogyvári F.; Lengyel C.; Fehértemplomi K.; Nyiraty S.; Kempler P. and Mándi Y., 2014. Relevance of defensins (HNP1-3) and defensin $\beta-1$ in diabetes. World Journal of Gastroenterology [Accepted for publication] IF: 2.547

Robb, R.J., 1984. Interleukin-2: The molecule and its function.Immunology today, 5:203

Sewing, L.; Steinberg F.; Schmidt H. and Goke R., 2008. The bisphosphonate zoledronic acid inhibits the growth of HCT-116 colon carcinoma cells and induces tumor cell apoptosis. Apoptosis, 13: 782-789.

Shi, Y. and Hu F.B., 2014. The global implications of diabetes and cancer. The Lancet. , 383: 1947-1948.

Silverman, S.L., 2008. Paget disease of bone: therapeutic options. J Clin Rheumatol, 14: 299-305.

Sirmahan, C.; Firat S. and Cengizhan K., 2012. Bisphosphonates and Bone, Orthopedic Surgery, Dr Zaid AlAubaidi (Ed.)

Stumvoll, M.; Goldstein B. J. and van Haeften T. W. , 2005. "Type 2 diabetes: principles of pathogenesis and therapy, "The Lancet, vol., 365: 1333-1346

Tang, W.; Yu-Qin Z.; Ting Z.; Jing-Li S.; Peng S.; Ting-Ting Y.; Xin-Wen C.;
Sen L.; Paulus S.W. and Dong-Ping X., 2011. Effect of Interleukin-6 (IL-6) on the Vascular Smooth Muscle Contraction in Abdominal Aorta of Rats with Streptozotocin-Induced Diabetes. Chinese Journal of Physiology, 54(5): 318-323

Tassone, P.; Tagliaferri P.; Viscomi C.; Palmieri C.; Caraglia M.; D’Alessandro A.; Galea E.; Goel A.; Abbruzzese A.; Boland C.R. and Venuta S., 2003. Zoledronic acid induces antiproliferative and apoptotic effects in human pancreatic cancer cells in vitro. $\mathrm{Br} \mathrm{J}$. Cancer, 88(12):1971-1978

Tassone, P.; ForcinitiS.; Galea E.; Morrone G.; Turco M. C.; Martinelli V.; Tagliaferri P. and Venuta S., 2000. "Growth inhibition and synergistic induction of apoptosis by zoledronate and dexamethasone in human myeloma cell lines," Leukemia, Vol. 14, No. 5, pp. 841-844.

Tassone, P.; Tagliaferri P. and Viscomi C., 2003. Zoledronic acid induces antiproliferative and apoptotic effects in human pancreatic cancer cells in vitro. Br J Cancer, 88: 1971-1978.

Wang, Z.; Zhang H.; Shen X.H.; Jin K.L. and Ye G.F., 2011. Immunoglobulin E and Mast Cell Proteases Are Potential Risk Factors of Human Pre-Diabetes and Diabetes Mellitus. Ann Med., 6(12): 28962.

Wu, D.; Ma J.; Bao S. and Guan H., 2015. Continuous effect with long-term safety in zoledronic acid therapy for polyostotic fibrous dysplasia with severe bone destruction. Rheumatology International, 35(4), 767-772. 
Biochemical Study of Anti-Inflammatory Effect of Osteoblastic Activator in Experimental Pancreatic Degeneration in Rat 